\title{
Analyzing and comparing the two grade- ten mathematics textbooks versions (Arabic and English) used in Abu Dhabi schools
}

\author{
Yousef Abosalem $^{1 *}$ \\ ${ }^{1}$ Khalifa University, UNITED ARAB EMIRATES
}

\begin{abstract}
This study was conducted to compare two grade- ten mathematics textbooks according to Bloom's Taxonomies. In the Arabic version, 37 out of 70 periods $(55.29 \%)$ were given to plane geometry and trigonometry, whereas 29 out of 70 periods $(41.41 \%)$ were allocated for geometry and trigonometry. Also, 12 periods $(17.14 \%)$ were allocated for algebra in the Arabic version, whereas 19 periods (27.14\%) in the English version. As concluded in the above percentages, more concentration was given to geometry in the Arabic version compared to Algebra in the English version. The results indicated that in the geometry chapter in the Arabic version, the educational objectives percentages ranged from $40.0 \%$ (comprehension) to 8.75 (synthesis and evaluation), and $62.86 \%$ of the educational objectives were in the lower levels of Bloom's Taxonomies. Whereas in the English version the Geometry chapter ranged from $45.65 \%$ (application) to 10.87\% (synthesis), and for the same chapters, $\quad 63.04 \%$ were in the lower levels of Bloom's taxonomies. For the Algebra chapter, the objectives ranged from $56.25 \%$ (application) to $6.25 \%$ ( synthesis and evaluation) and from $47.62 \%$ (application) to $4.76 \%$ (comprehension and synthesis) in the Arabic and English versions respectively. With respect to educational objectives, 79.11 $\%$ of the educational objectives were at the application level in Arabic version compared to $93.27 \%$ for the application in the English one.
\end{abstract}

\author{
Keywords \\ analysis, \\ textbook, \\ mathematics, \\ grade ten, \\ Bloom's Taxonomies, \\ Abu-Dhabi
}

\section{INTRODUCTION}

Curricula analysis is a continuous process. It has to be conducted from time to time in order to improve and develop curriculum. Many researchers (e.g. Kline 1974, p. 98) argue that mathematics curricula are supposed to be comprehensive, and appropriate to the rapid changes in knowledge development. Moreover, Kline (1974) in his book titled Why Johnny cannot add? Stated that: mathematics curricula have many deficiencies that can be summarized in: concepts, facts, rules and processes that are presented with no connection between them. In mathematical mistakes occur in clarifying these concepts and facts, as well as contain unnecessary topics that are not helpful and can't be used by students in their future studies or careers. Furthermore, Kline stated that the existent mathematics curricula are suffering from a lack of motivation and thrill.

\footnotetext{
${ }^{*}$ Correspondence to: yousef.abosalem@kustar.ac.ae

Pedagogical Research, 2016. (C) 2016 Yousef Abosalem. This is an Open Access article distributed under the terms of the Creative Commons Attribution 4.0 International License (http://creativecommons.org/licenses/by/4.0/), allowing third parties to copy and redistribute the material in any medium or format and to remix, transform, and build upon the material for any purpose, even commercially, provided the original work is properly cited and states its license.
} 
Madaus and Kellaghan (1992, p.132) stated that the use of an objective approach in curricula analysis received considerable interest after the publication of educational objectives taxonomies by Bloom (1956). Researchers in testing and in evaluation to determine the extent to which these questions comply with the learning objectives and learning theories (Ayvaci \& Turkdogan 2010, p. 15; Scott 1972, p. 412) use Bloom's taxonomy closely. According to Bloom, the educational objectives are divided into three domains: cognitive, affective and psychomotor domains.

According to Andeson, et al. (2001, p.75) comparing is "detecting similarities and differences between two or more things". In this paper, Bloom's taxonomy - cognitive domain- will be used to compare two grade-10 mathematics textbook versions (Arabic and English) that are being used and implemented in Abu Dhabi Education Council (ADEC). In Abu-Dhabi schools, some private schools are using the old mathematic curriculum (Arabic version) whereas, government schools are implementing a new mathematics curricula (English version).

In this paper, the document analysis approach was employed to describe the textbooks' contents quantitatively and qualitatively. There are three domains for content analysis. Knowledge domain, which includes the mathematical content (Numbers and operations, Geometry, Statistics and Algebra) with all concepts and skills. The second domain is behavior which identifies the relationship between the mathematical contents and changes that might occur in student's behavior and the reflection of this behavior on the student's abilities in higher order thinking skills and problem solving abilities. The third domain can be characterized by designing teaching strategies that are suitable for that content and includes Bloom's taxonomies that will create changes in students' behavior and achieving learning goals.

The importance of this analysis process came from other research conducted by Abosalem (2009) that aimed at evaluating grade-10 mathematics curricula (English version) from teachers' perspectives. The results showed that grade-10 mathematics curriculum needs improvements in many aspects such as teaching aids, and evaluation techniques used by mathematics teachers. In addition, participants also reported that the area of content domain was the best of the four domains investigated in this study. So that, this paper will try to shed light on the differences and similarities between the two mathematics curricula versions according to Bloom's Taxonomies.

\section{OVERVIEW OF UAE / ABU DHABI EDUCATIONAL SYSTEM}

\section{Academic mathematics in the 10 12 Abu Dhabi curriculum}

In many countries around the world, a new movement of science and mathematics curricula reform is taking place. There are many different reasons behind that; for example, there is a vast demand for a mathematics curriculum which has the ability to engage students in mathematics in real life situations and everyday lives. In addition, this is also happening because curriculum is a major lever for promoting change and enhancement in school mathematics programs (Hirsch \& Reys 2009, p. 753). The new curriculum should provoke students' interest in learning mathematics, and develop students' mathematical thinking (Li et al., 2009, p.738).

New mathematics curricula have been developed and are being implemented in Abu Dhabi in the United Arab Emirates (UAE). The reason for that change is to move teaching mathematics from the traditional curriculum to a standards- based one. The focus of the new curriculum is to improve students' mathematical abilities, and to implement mathematics in real life situations.

The Abu Dhabi Education Council (ADEC) considers the final three years in the UAE schooling system vital for every student in order to build and prepare students' mathematical knowledge, which will provide them with a strong foundation that is required for students' future learning.

The mandated grade-10 curriculum implementation in 2008 is for students pursuing an academic area at university that requires mathematics. It aims at developing students' ability to use and employ their mathematical knowledge in real life situations and involves a wide range of learning contexts and situations. Furthermore, it aims to develop students' ability to use concepts, techniques and technological applications to solve problems. The new mathematics curriculum is supposed to concentrate on active learning, i.e. to enhance the students' abilities in problem-solving, discovering and exploring techniques. Furthermore, new curricula have to connect the mathematical content with real and reasonable situations.

To improve education, to benefit from international expertise, and to prepare students for the next generation, the UAE Ministry of Education/Abu Dhabi Educational Council (ADEC) is in the process of revising and reconstructing school's curricula for different subjects in order to train students to be the future 
scientists, engineers and managers in Abu Dhabi society and region. That calls for a great shift in priorities in teaching, and demands a more rigorous curriculum, which means moving from a traditional curriculum to astandards-based one. That shift to a standards-based curriculum requires changes in the teaching practice, assessment techniques, and intensive professional development programs for teachers, so they can teach in other ways than the traditional ones. As a result, this will enhance the already innovative practice of teachers. Furthermore, Obara and Sloan (2009, p. 13) argue that teachers should use a standards-based curriculum as it encourages teachers to share experiences and support each other as they change their practice.

\section{Traditional \& standards-based curricula}

The organization of schooling and future education has long been connected with the idea of a curriculum, and how it might be conceptualized and implemented. A useful starting point in this paper might be the definition of curriculum.

Varying definitions exist for curriculum in educational literature. The National Research Council (2004, p. 38) defines curriculum as "a set of materials for use at each grade level, a set of teacher guides, and accompanying classroom assessments. It may consist of a listing of prescribed or preferred classroom manipulatives or technologies, materials for patterns, homework booklets and so forth". Whereas, Gerald and $\mathrm{Li}$ (2009, p. 709) consider curriculum as an "outline of teaching and learning requirements in content and performance, it is developed to structure students' learning experiences in schools". In this paper, mathematics curriculum can be considered as a whole system, consisting of aims, teaching methods, content, educational activities, and assessment techniques.

The traditional curriculum focused on skills and is considered a central theme in a new curriculum, but teachers now introduce these skills in real-world contexts that enable students to investigate and solve problems. Rontzur, et al. (2001, p. 232) pointed out that word problems and traditional activities of telling and showing the mathematics students need to know is the main target for the traditional school curricula. Furthermore, Verschaffel (2002, p. 65) described the goal of a word problem as "to bring reality into the mathematics classroom, to create occasions for learning and practicing the different aspects of applied problem solving, without the practical ... inconveniences of direct contact with the real world situation". Furthermore, it can be characterized by teachers' attempts to transmit particular mathematical ideas to students.

On the other hand, Deborah (1998, p. 62) defined a "standard- based" curriculum as being different from traditional mathematics curriculum in that it encourages teachers to enhance educational experiences that support problem-solving, logic, communication, and make meaningful connections between mathematical ideas. Moreover, it considers that the teaching to be about helping students to see the intended mathematics. Furthermore, Remillard (2005, p. 234) considered it as "a responsive and improvisational activity that cannot be scripted". Furthermore, it builds students' understanding of important mathematics through explorations of real world situations and problems (Nie et al., 2009, p. 782). Standards-based materials are comprehensive and coherent and develop ideas in depth; therefore, they will enhance students' performance in mathematics (Reys et al., 2003, p. 81; Riordan \& Noyce, 2001, p.375; Nie et al., 2009, p.785). However, Ross and Ford (2008, p. 364) argue that standards-based teaching is not appropriate for low achiving students. Thus, the role of the teacher is to create chances for students to conceive, and direct the intended aspects of mathematics, as well as creating conditions that employ students actively in considering and linking these ideas. Therefore, I believe that teaching is the theme of the involvement of students in significant problems and facilitating discussions about these issues, and to encourage questioning and speculating, and the problem formulation, as well as appreciating student thoughts processes and use of multiple strategies in learning.

\section{LITERATURE REVIEW}

For many mathematics teachers, the textbook is the primary guide in implementing and delivering each lesson's content. It provides a framework for thinking about what will be taught, and sequence for how it could be taught, to whom, and when (Nicol \& Crespo 2006, p. 345) and the mathematical content that should be given prominence in class. Pepin and Haggarty (2001, p.162) both argue that the textbook connects the knowledge domains to school subjects, and introduces, if previous change is made, lists of topics to be covered, assignments to be completed and the content activities that are supposed to be explored; thus, it has a direct impact on what schools teach and what students learn. Moreover, textbooks provide the main components of the daily lesson plans and what teachers want students to learn. Thus, the goal is to link high quality instruction in mathematics classrooms to the textbook's content, and thus what is 
enacted in the classroom requires that teachers design high quality lesson plans that can be achieved through a high-quality textbook (Li , 2002, p. 183; Li \& Gerald 2009, p. 746). Furthermore, scholars argued that the textbook provides students not only with mathematics but also offers students "ubiquitous and as a prominent, if not dominant, part of teaching and learning" (Nie et al., 2009, p.785; Tornroos 2005, p. 753). Moreover, it has a vital role in organizing the teaching learning processes. Along with that, textbooks are necessary for exams, and going through worked examples and enhancing their learning. Nevertheless, a good or even great textbook alone will not create significant changes in the classroom. Imparting and implementing a lesson requires the skills of the teacher. Teachers often alter textbooks, and as a result, they need to be given stronger incentives or sanctions to stick to or amend/adapt their course text(s), as well as information on how to use each textbook in class.

\section{Textbook analysis}

Textbook analysis was defined by Evelyn (2005, p.95) and Ronald (1996, p.121) as being a broad and continuous effort to inquire into the effects of utilizing educational content and process as well as the degree to which this is implemented to meet or attain clearly defined objectives.

The tendencies in evaluating, analyzing and developing mathematics textbooks recently are due to not only embodying new concepts or deleting old ones, but as an essential step to ensure that the topic covered by the textbook or a teaching unit will actually assist students in learning the content. Moreover, Ronald (1996, p.125) argues that it is also to validate whether the major textbook changes presented in previous years had been set up to make real improvements. Textbook analysis is not a purpose, but is a process to produce a high-quality textbook; consequently high quality instruction in mathematics classrooms occurred. It can be used for alignment between content and the selected learning objectives that identify what we want students to learn. In addition, textbook analysis is important to understand its effects on students' learning. The purpose here is to determine, mentioning evidence from the materials, whether the content matches specific learning objectives, not just whether the topic headings are similar. Moreover, there is a demand for a curriculum that has the ability to achieve the teaching objectives, and to serve other science subjects in clarifying their concepts. In addition, a good curriculum is designed to help teachers operate more thoughtfully and effectively in their classes (Debrah \& David 1996, p.7). Additionally, it will provide students with opportunities to learn and apply their learning in different contexts (Bulut 2007, p.209).

High school textbook analysis has two facets: diagnostic and remedial. As a diagnostic process it reveals weakness areas, and by identifying theses areas, educators can conquer and rectify them. As a remedial process, it leads to the enhancement of the teaching-learning processes by outlining the teaching objectives and providing teachers, administration and curricula developers with information on the curriculum effectiveness. Consequently, it provides rationalization for ongoing research to comprehend mathematics classrooms from the teachers' perspective when we try to improve the teaching of the mathematics process.

Mathematics teachers in all countries rely heavily on textbooks in their day-to-day teaching. But textbooks use is different from one teacher to another. Mathematics teachers and schools use textbooks in varying ways and to different degrees (Heirdsfield, Dole \& Warren 2008, p. 26). Remillard (2005, p.231) argues that textbooks use is how specific teachers interact with, utilize, consult, and are influenced by material resources designed to guide teaching and this is perhaps more characteristic of the teaching of mathematics than of any other subjects. Thus, teachers decide what to teach, how to teach it, and what sorts of exercises to assign to their students largely based on what is contained in the curriculum authorized for their course (Robitaille \& Travers 1992, p.701; Haggarty \& Pepin 2002, p. 573; Pepin \& Haggarty 2001, p. 164; Özgeldi, 2010).

Ziegler and Chapman (2004, p.15) have both stated that because teachers are the decisive factor in implementing mathematics curriculum in class, it is very important to hear from them (i.e., their perspectives) in terms of what they do and how they make sense of what they do during their teaching in classes. Moreover, teachers often use the textbook as their primary resource to plan daily mathematics instruction (Weiss et al., 2001, p. 84).

The textbook has come to play three crucial roles: First, it determines how the teacher will sequence material. In a tenth grade mathematics textbook, for example, early chapters focus on Patterns and Algebra, which introduces students to solving simple linear equations before solving equations that are more complex. Furthermore, the textbook suggests the content that teachers are supposed to teach. The third crucial role played by the textbook is to provide teachers with learning activities, how students will learn what teachers want them to learn, and instructional ideas for engaging students in the topic presented. The textbook serves as a set of lesson plans for teachers, complete with sample problems, diagrams, worked- out examples, and homework assignments. The number of pages that the textbook allots to a specific topic influences the 
amount of time that the teacher spends on that topic (Chaves, 2003, p. 36). Not surprisingly, the teacher often mirrors the textbook's method of presentation. However, Remillard (2005) considers teacher as an active designer of the curriculum rather than a conduit or implementer.

\section{Grade-10 mathematics curriculum (Arabic version) description}

This curriculum is divided into two parts. Part one consists of three distinct chapters: Trigonometry, Analytic geometry and Algebra. Whereas, the second part includes four chapters: Further Algebra, Plane Geometry, Trigonometry, and Statistics. For the purpose of this paper, the focus will be on the second part of the grade-10 mathematics curriculum. The Algebra chapter covers: Solving Quadratic Equations in One Variable, Triangles Similarity, and Circles; Chords and Tangent Segments and Applications on Space Geometry covered in the second chapter. The third chapter of the textbook deals with using calculators, solving right triangles, angles of elevation and depression, the unit circle, relations among triangular functions. Data analysis, quartiles, standard deviation, using a calculator to find the mean and standard deviation, and samples are presented on the last chapter (Lebanon, 2008).

\section{Grade-10 mathematics curriculum (English version) description}

This version is divided into four strands; Number Patterns, Algebra, Measurement and Data, and Space and Geometry. It consists of fourteen chapters distributed into two parts or semesters. In the first semester, the teacher has to cover seven chapters: Review of Grade-9, Congruent Triangles, Probability, Simultaneous Equations, Coordinate Geometry, Surface Area and Volume, and Statistics. Whereas, the second semester includes: Similar Triangles, Further Algebra, Further Equations, Further Numbers, Further Deductive Geometry, Curve Sketching, and Further Trigonometry (McServeny et al., 2008; ADEC 2008, pp.7-9).

\section{ANALYSIS PROCEDURES}

According to tables 1 and 2, both versions were allocated the same total number of periods in order to deliver the contents. However, in the Arabic version more concentration was given to geometry (Plane geometry and Trigonometry), 37 periods out of 70(55.29\%). Whereas, in the English version 29 periods out of $70(41.40 \%)$ were allocated for geometry (Similar Triangles, Further Deductive Geometry, and Further Trigonometry). In the Arabic version, 12 periods out of 70 (17.14\%) were allocated for Algebra, in comparison to 19 periods out of $70(27.14 \%)$ in the English version. From the percentages mentioned above it can be concluded that the Arabic version allocated more attention to geometry topics, whereas, in the English version the concentration was given to Algebra.

The two versions of the grade-10 mathematics contents were analyzed. For the purpose of this paper and for the common things between chapters, the contents of the two textbooks were combined into the following topics: Geometry Similar Triangles, Trigonometry and Algebra in the English version. Plane geometry, Trigonometry and Algebra were combined in the Arabic version.

Table 1. The time distribution for the Arabic version

\begin{tabular}{cc}
\hline Chapter & Number of Periods \\
\hline Further Algebra & 12 \\
Plane Geometry & 21 \\
Trigonometry & 16 \\
Statistics & 16 \\
Revision & 3 \\
Evaluation & 1 \\
Result's Analysis & 1 \\
Total & 70 periods \\
\hline
\end{tabular}

Table 2. The time distribution for the English version

\begin{tabular}{cc}
\hline Chapter & Number of Periods \\
\hline Similar Triangles & 9 \\
Further Algebra & 11 \\
Further Equations & 8 \\
Further Numbers & 7 \\
Further Deductive Geometry & 10 \\
Curve Sketching & 15 \\
Further Trigonometry & 10 \\
Total & 70 periods \\
\hline
\end{tabular}


Tables 3, 4, 5, and 6 show 118 educational objectives analyzed according to Bloom's Taxonomy (Knowledge, Comprehension, Application, Analysis, Synthesis, and Evaluation) for the two mathematics textbook versions.

Table 3. The analysis of the educational objectives according to the Bloom's Taxonomy for Geometry chapters (English version)

\begin{tabular}{|c|c|c|c|c|c|c|c|}
\hline No. & $\begin{array}{l}\text { Behavioral Objectives Similar Triangles- } \\
\text { Geometry \& Trigonometry Chapters (English Version) }\end{array}$ & $\mathrm{Knw}^{\mathrm{a}}$ & Comp ${ }^{b}$ & App ${ }^{c}$ & Analy ${ }^{\mathrm{d}}$ & Synt ${ }^{\mathrm{e}}$ & Eval $^{\mathrm{f}}$ \\
\hline 1 & To apply tests for congruent triangles & & & $\mathrm{X}$ & & & \\
\hline 2 & $\begin{array}{l}\text { Use simple deductive reasoning in numerical and nonnumeric } \\
\text { problems }\end{array}$ & & & $\mathrm{X}$ & & & \\
\hline 3 & $\begin{array}{l}\text { Construct proofs of geometrical relationships involving } \\
\text { congruent or similar triangles }\end{array}$ & & & & $X$ & & \\
\hline 4 & $\begin{array}{l}\text { Use simple deductive geometry to prove properties of special } \\
\text { triangles and quadrilaterals }\end{array}$ & & & & & $\mathrm{X}$ & \\
\hline 5 & $\begin{array}{l}\text { Construct geometrical arguments, using similarity tests for } \\
\text { triangles }\end{array}$ & & & & $\mathrm{X}$ & & \\
\hline 6 & Explore and use similarity relationships for area and volume & & $\mathrm{X}$ & & & & \\
\hline 7 & $\begin{array}{l}\text { To use the term similar for any two figures that have the same } \\
\text { shape but not necessarily the same size }\end{array}$ & & & $\mathrm{X}$ & & & \\
\hline 8 & To match the sides and angles of similar figures & & $\mathrm{X}$ & & & & \\
\hline 9 & To determine the scale factor for a pair of similar polygons & & & $\mathrm{X}$ & & & \\
\hline 10 & $\begin{array}{l}\text { To calculate the dimensions of similar figures using the } \\
\text { enlargement or reduction factor }\end{array}$ & & $\mathrm{X}$ & & & & \\
\hline 11 & $\begin{array}{l}\text { To investigate whether any two triangles, or any two isosceles } \\
\text { triangles, are similar }\end{array}$ & & & $\mathrm{X}$ & & & \\
\hline 12 & $\begin{array}{l}\text { To explain why any two equilateral triangles, or any two squares, } \\
\text { are similar, and explain when they are congruent }\end{array}$ & & & & $\mathrm{X}$ & & \\
\hline 13 & $\begin{array}{l}\text { To use dynamic geometry software to investigate the properties } \\
\text { of geometrical figures }\end{array}$ & & & $\mathrm{X}$ & & & \\
\hline 14 & $\begin{array}{l}\text { To identify congruent and similar two-dimensional figures } \\
\text { stating the relevant conditions }\end{array}$ & & & $\mathrm{X}$ & & & \\
\hline 15 & $\begin{array}{l}\text { To develop and apply results for proving that triangles are } \\
\text { congruent or similar }\end{array}$ & & & & $\mathrm{X}$ & & \\
\hline 16 & $\begin{array}{l}\text { To identify the elements preserved in similar triangles, namely } \\
\text { angle size and the ratio of corresponding sides }\end{array}$ & & & $\mathrm{X}$ & & & \\
\hline 17 & To determine whether triangles are similar & & $\mathrm{X}$ & & & & \\
\hline 18 & $\begin{array}{l}\text { To Apply simple deductive reasoning in solving numerical and } \\
\text { non-numerical problems }\end{array}$ & & & X & & & \\
\hline 19 & To calculate unknown sides in a pair of similar triangles & & & $\mathrm{X}$ & & & \\
\hline 20 & $\begin{array}{l}\text { To apply the properties of congruent and similar triangles to } \\
\text { solve problem, justify the results }\end{array}$ & & & $\mathrm{X}$ & & & \\
\hline 21 & $\begin{array}{l}\text { To apply the enlargement or reduction factor to find unknown } \\
\text { sides in similar triangles }\end{array}$ & & & $\mathrm{X}$ & & & \\
\hline 22 & $\begin{array}{l}\text { To recognize that shape, angle size and the ratio of matching } \\
\text { sides are preserved in similar figures }\end{array}$ & & $\mathrm{X}$ & & & & \\
\hline 23 & To prove statements about geometrical figures & & & & $\mathrm{X}$ & & \\
\hline 24 & To solve problems using deductive reasoning & & & & $\mathrm{X}$ & & \\
\hline 25 & To make refine and test conjectures & & & $\mathrm{X}$ & & & \\
\hline 26 & $\begin{array}{l}\text { To state possible converses of known results, and maximize } \\
\text { whether or not they are also true }\end{array}$ & & $\mathrm{X}$ & & & & \\
\hline 27 & $\begin{array}{l}\text { To use dynamic geometry software to investigate and test } \\
\text { conjectures about geometrical figures }\end{array}$ & & & $\mathrm{X}$ & & & \\
\hline 28 & $\begin{array}{l}\text { To apply the congruency tests to justify that two triangles are } \\
\text { congruent }\end{array}$ & & & & $\mathrm{X}$ & & \\
\hline 29 & $\begin{array}{l}\text { To write formal proofs of congruence of triangles, preserving } \\
\text { matching order of vertices }\end{array}$ & & & & $\mathrm{X}$ & & \\
\hline 30 & $\begin{array}{l}\text { To construct and write geometrical arguments to prove a } \\
\text { general geometrical results, giving reasons at each step of the } \\
\text { argument }\end{array}$ & & & & $\mathrm{X}$ & & \\
\hline
\end{tabular}




\begin{tabular}{|c|c|c|c|c|c|}
\hline 31 & To solve Euclidean problems & & $\mathrm{X}$ & & \\
\hline 32 & $\begin{array}{l}\text { To use and interpret formal definitions when presenting a } \\
\text { deductive argument }\end{array}$ & & & $\mathrm{X}$ & \\
\hline 33 & $\begin{array}{l}\text { To reason that any result proven for a parallelogram would also } \\
\text { hold for a rectangle }\end{array}$ & & & $\mathrm{X}$ & \\
\hline 34 & $\begin{array}{l}\text { To give reasons why square is a rhombus, but a rhombus is not } \\
\text { necessarily a square }\end{array}$ & & & & $\mathrm{X}$ \\
\hline 35 & $\begin{array}{l}\text { To solve arithmetic and non-arithmetic problems in Euclidean } \\
\text { geometry based on known assumptions and proven theorems }\end{array}$ & & $\mathrm{X}$ & & \\
\hline 36 & $\begin{array}{l}\text { To apply formulae to find the surface area of pyramids, right } \\
\text { cones and spheres and find the area and volume of similar solids }\end{array}$ & & $\mathrm{X}$ & & \\
\hline 37 & $\begin{array}{l}\text { To apply trig. Relationships, sine rule, cosine rule, and area rule } \\
\text { in problem solving }\end{array}$ & & $\mathrm{X}$ & & \\
\hline 38 & To determine the exact trig. Ratios for 30,45 , and 60 angles & & $\mathrm{X}$ & & \\
\hline 39 & $\begin{array}{l}\text { To apply relationships in trig. For complementary for } \\
\text { complementary angles and tan in terms of sine and cosine }\end{array}$ & $\mathrm{X}$ & & & \\
\hline 40 & To determine trig. Ratios for obtuse angles & $\mathrm{X}$ & & & \\
\hline 41 & $\begin{array}{l}\text { To sketch sine and cosine curves, explore trig. With non-right- } \\
\text { angled triangles, sine rule, cosine rule and area rule }\end{array}$ & & $\mathrm{X}$ & & \\
\hline 42 & To solve problems involving more than one triangle using trig. & & & & $\mathrm{X}$ \\
\hline 43 & $\begin{array}{l}\text { To use sine rule to find unknown sides and angles of a triangle, } \\
\text { including in problems in which there are two possible solutions } \\
\text { for an angle }\end{array}$ & & $\mathrm{X}$ & & \\
\hline 44 & $\begin{array}{l}\text { To draw diagrams and using them to solve word problems that } \\
\text { involve non-right-angled triangles }\end{array}$ & & & $\mathrm{X}$ & \\
\hline 45 & $\begin{array}{l}\text { To solve problems, including practical problems, involving the } \\
\text { sine and cosine rules and the area rule }\end{array}$ & & & & $\mathrm{X}$ \\
\hline 46 & $\begin{array}{l}\text { To use appropriate trig. Ratios and formulae to solve two- } \\
\text { dimensional trig. Problems that require the use of more than } \\
\text { one triangle }\end{array}$ & & & & $X$ \\
\hline
\end{tabular}

Table 4. The analysis of the educational objectives according to Bloom's Taxonomy for geometry chapters (Arabic version)

\begin{tabular}{|c|c|c|c|c|c|c|c|}
\hline No. & $\begin{array}{l}\text { Behavioral Objectives Plane geometry and } \\
\text { Trigonometry Chapters(Arabic Version) }\end{array}$ & $\mathrm{Knw}^{\mathrm{a}}$ & Comp ${ }^{\mathrm{b}}$ & App & Analyd & Synte & Evalf $^{\mathrm{f}}$ \\
\hline 1 & To Recognize The plane geometry concept & & $\mathrm{X}$ & & & & \\
\hline 2 & $\begin{array}{l}\text { To realize the similarity concept between geometrical } \\
\text { figures }\end{array}$ & & $\mathrm{X}$ & & & & \\
\hline 3 & $\begin{array}{l}\text { To conclude that triangle similarity is broader than triangle } \\
\text { congruent }\end{array}$ & & $\mathrm{X}$ & & & & \\
\hline 4 & $\begin{array}{l}\text { To realize that triangle similarity is either enlargement } \\
\text { reduction or congruent }\end{array}$ & & $\mathrm{X}$ & & & & \\
\hline 5 & $\begin{array}{l}\text { To realize that triangle similarity is the proportion between } \\
\text { the side's lengths and equality of angles' measures }\end{array}$ & & $\mathrm{X}$ & & & & \\
\hline 6 & $\begin{array}{l}\text { To find the similarity ratios between two triangles or two } \\
\text { polygons }\end{array}$ & & & $\mathrm{X}$ & & & \\
\hline 7 & $\begin{array}{l}\text { To compare between the similarity ratios ( the ratio } \\
\text { between two matching sides) and the ratio between } \\
\text { perimeters and areas of similar figures }\end{array}$ & & & $\mathrm{X}$ & & & \\
\hline 8 & $\begin{array}{l}\text { To recognize some of the similarity theorems and connect } \\
\text { them }\end{array}$ & & $\mathrm{X}$ & & & & \\
\hline 9 & To develop theoretical proof skills & & & & $\mathrm{X}$ & & \\
\hline 10 & $\begin{array}{l}\text { To construct some of geometrical figures with a specific } \\
\text { conditions }\end{array}$ & & & $\mathrm{X}$ & & & \\
\hline 11 & $\begin{array}{l}\text { To connect between the similarity theorems and similarity } \\
\text { results in the right angled triangles and other type of } \\
\text { triangles }\end{array}$ & & & & $\mathrm{X}$ & & \\
\hline 12 & $\begin{array}{l}\text { To use similarity properties in discovering some } \\
\text { relationships related to circles' chords and tangents }\end{array}$ & & & & $\mathrm{X}$ & & \\
\hline
\end{tabular}


13 To use different arithmetic methods( mental, technical) to

$\mathrm{X}$ calculate the dimensions of some polygons and circles figures

14 To apply his theoretical knowledge in practical situations including aspects can be used in space geometry

15 To recognize the golden ratio concept and use it in drawing rectangles have the same golden ratio

16 To use similarity in real life situations

17 To appreciate scientists role in in discovering the golden ratio and use it in arts

18 To use calculators to find trig. Functions effectively

19 To realize the concept of solving triangle

20 To solve right angled triangle

21 To recognize that trigonometry came from astronomy and used for indirect measurements

22 To appreciate the Egyptian and Arabic civilization in developing the trig. Topics

23 To realize the concepts of angle of elevation and depression

24 To recognize the concept of tri. Functions in unit circle and use it in simplifying the relationships between them

25 To recognize that trig. Functions is another type of mathematical functions

26 To conclude arithmetically or algebraically when the values of trig. Functions increase or decrease according to the angles' measures, and the quartiles

27 To conclude that the trig. Functions and their reciprocals have the same signs at a specific point

28 To conclude that trig. Functions are real functions

29 To appreciate the excitement of proving trig. Identities

30 To prove trig. Identities by substitution

31 To conclude some relations by mathematical induction

32 To use trigonometry in real life situation

33 To solve problems including angles of elevation and depression

34 To solve trig. Equations

35 To recognize the relationship between trig. Functions

${ }^{a}$ Knowledge, ${ }^{b}$ Comprehension, ${ }^{c}$ Application, dAnalysis, eSynthesis, ${ }^{f}$ Evaluation

$\mathrm{X}$

$$
\text { X }
$$

$\mathrm{X}$

$\mathrm{X}$

$\mathrm{X}$

$\mathrm{X}$

$\mathrm{X}$

$\mathrm{X}$

$\mathrm{X}$

$\mathrm{X}$

$\mathrm{X}$

$\mathrm{X}$ $\mathrm{X}$

$\mathrm{X}$

$\mathrm{X}$

Table 5. The analysis of the educational objectives according to Bloom's Taxonomy for algebra chapters (English version)

\begin{tabular}{|c|c|c|c|c|c|c|c|}
\hline No. & $\begin{array}{l}\text { Behavioral Objectives Algebra Chapter } \\
\text { (English Version) }\end{array}$ & $\mathrm{Knw}^{\mathrm{a}}$ & Comp ${ }^{b}$ & $A p p^{c}$ & Analy ${ }^{\mathrm{d}}$ & Synt ${ }^{\mathrm{e}}$ & Evalf $^{\mathrm{f}}$ \\
\hline 1 & $\begin{array}{l}\text { To use algebraic techniques to simplify expressions, } \\
\text { expand binomial products, factorize quadratics } \\
\text { expressions }\end{array}$ & & & $\mathrm{X}$ & & & \\
\hline 2 & $\begin{array}{l}\text { To develop facility with the algebraic symbol system } \\
\text { in order to apply algebraic techniques to other strands } \\
\text { and sub-strands }\end{array}$ & & & & $\mathrm{X}$ & & \\
\hline 3 & To link algebra with generalized arithmetic & & & & $\mathrm{X}$ & & \\
\hline 4 & $\begin{array}{l}\text { To check expansions and factorizations by } \\
\text { performing the reverse process }\end{array}$ & & & & $\mathrm{X}$ & & \\
\hline 5 & To factorize expressions: Trinomials & & & $\mathrm{X}$ & & & \\
\hline 6 & To use variety of methods to factorize expressions & & & $\mathrm{X}$ & & & \\
\hline 7 & $\begin{array}{l}\text { To factorize and simplify a variety of more complex } \\
\text { algebraic expressions }\end{array}$ & & & & $\mathrm{X}$ & & \\
\hline 8 & $\begin{array}{l}\text { To solve quadratic equations by factorizing, } \\
\text { completing the square or using the quadratic formula }\end{array}$ & & & & $\mathrm{X}$ & & \\
\hline 9 & $\begin{array}{l}\text { To solve a range of inequalities and rearrange literal } \\
\text { equations }\end{array}$ & & & & & $\mathrm{X}$ & \\
\hline 10 & $\begin{array}{l}\text { To solve simultaneous linear equations, including one } \\
\text { quadratic equation }\end{array}$ & & & $\mathrm{X}$ & & & \\
\hline 11 & To check the solutions of quadratic equations & & & $\mathrm{X}$ & & & \\
\hline
\end{tabular}




\begin{tabular}{|c|c|c|c|c|}
\hline 12 & $\begin{array}{l}\text { To discuss the possible number of roots for any } \\
\text { quadratic equation }\end{array}$ & & $\mathrm{X}$ & \\
\hline 13 & $\begin{array}{l}\text { To choose the most appropriate method to solve a } \\
\text { particular quadratic equation }\end{array}$ & & $\mathrm{X}$ & \\
\hline 14 & To generate quadratic equations from problems & $\mathrm{X}$ & & \\
\hline 15 & To solve problems involving quadratic equations & & & $\mathrm{x}$ \\
\hline 16 & $\begin{array}{l}\text { To use analytical methods to solve a variety of } \\
\text { simultaneous equations }\end{array}$ & & & $\mathrm{X}$ \\
\hline 17 & $\begin{array}{l}\text { To solve non-routine problems using algebraic } \\
\text { techniques }\end{array}$ & & $\mathrm{X}$ & \\
\hline 18 & $\begin{array}{l}\text { To create equations to solve a variety of problems } \\
\text { and check solutions }\end{array}$ & & $\mathrm{X}$ & \\
\hline 19 & $\begin{array}{l}\text { To explain why a particular method to solve a } \\
\text { particular quadratic equation }\end{array}$ & & & $\mathrm{X}$ \\
\hline 20 & $\begin{array}{l}\text { To graph simultaneous equations to find solutions } \\
\text { and compare this method with analytic methods }\end{array}$ & & & $\mathrm{X}$ \\
\hline 21 & To change the subject of a formula & & $\mathrm{X}$ & \\
\hline
\end{tabular}

aKnowledge, ${ }^{b}$ Comprehension, c Application, dAnalysis, ${ }^{e}$ Synthesis, $f$ Evaluation

Table 6. The analysis of the educational objectives according to Bloom's Taxonomy for Algebra chapters (Arabic version)

\begin{tabular}{|c|c|c|c|c|c|c|c|}
\hline No. & $\begin{array}{l}\text { Behavioral Objectives Algebra } \\
\text { Chapter(Arabic Version) }\end{array}$ & $\mathrm{Knw}^{\mathrm{a}}$ & Comp ${ }^{b}$ & $A p p^{c}$ & Analy & Synt ${ }^{\mathrm{e}}$ & Eval $^{\mathrm{f}}$ \\
\hline 1 & $\begin{array}{l}\text { To recognize the quadratic equation concept } \\
\text { in one variable }\end{array}$ & & $\mathrm{X}$ & & & & \\
\hline 2 & $\begin{array}{l}\text { To recognize different forms of quadratic } \\
\text { equation }\end{array}$ & & $\mathrm{x}$ & & & & \\
\hline 3 & $\begin{array}{l}\text { To recognize the Algorithm Approach in } \\
\text { solving quadratic equation by completing the } \\
\text { square method }\end{array}$ & & & $\mathrm{x}$ & & & \\
\hline 4 & $\begin{array}{l}\text { To recognize the existents of quadratic } \\
\text { equation formula to solve it }\end{array}$ & & $\mathrm{X}$ & & & & \\
\hline 5 & $\begin{array}{l}\text { To solve quadratic equation by using the } \\
\text { formula }\end{array}$ & & & $\mathrm{X}$ & & & \\
\hline 6 & $\begin{array}{l}\text { To recognize the graph of quadratic functions } \\
\text { in one variable }\end{array}$ & & $\mathrm{X}$ & & & & \\
\hline 7 & $\begin{array}{l}\text { To sketch the graph of quadratic function by } \\
\text { solving the quadratic equation }\end{array}$ & & & $\mathrm{X}$ & & & \\
\hline 8 & $\begin{array}{l}\text { To identify the relationship between the } \\
\text { discriminant and the intersection of the } \\
\text { quadratic equation with the } x \text {-axis }\end{array}$ & & & $\mathrm{X}$ & & & \\
\hline 9 & $\begin{array}{l}\text { To solve real life problems contain quadratic } \\
\text { equations }\end{array}$ & & & & $\mathrm{X}$ & & \\
\hline 10 & $\begin{array}{l}\text { To form the quadratic equation if the two } \\
\text { roots are given }\end{array}$ & & & $\mathrm{X}$ & & & \\
\hline 11 & $\begin{array}{l}\text { To realize that number of quadratic equations } \\
\text { have the same two roots is infinity }\end{array}$ & & & & & $\mathrm{X}$ & \\
\hline 12 & $\begin{array}{l}\text { To differentiate between the graphs of } \\
\text { different quadratic functions according to the } \\
\text { coefficient of leading term }\end{array}$ & & & $\mathrm{X}$ & & & \\
\hline 13 & $\begin{array}{l}\text { To appreciate the mathematicians role in the } \\
\text { Islamic civilization in the development of } \\
\text { mathematical thinking }\end{array}$ & & & & & & $\mathrm{X}$ \\
\hline 14 & To solve quadratic equation by formula & & & $\mathrm{X}$ & & & \\
\hline 15 & To solve quadratic equation by factorization & & & $\mathrm{X}$ & & & \\
\hline 16 & $\begin{array}{l}\text { To solve quadratic equation by completing } \\
\text { the square }\end{array}$ & & & $\mathrm{X}$ & & & \\
\hline
\end{tabular}


The percentages of each level of Bloom's Taxonomy were calculated as shown in Table 7 and presented on Figures 1, 2, 3, 4, and 5.

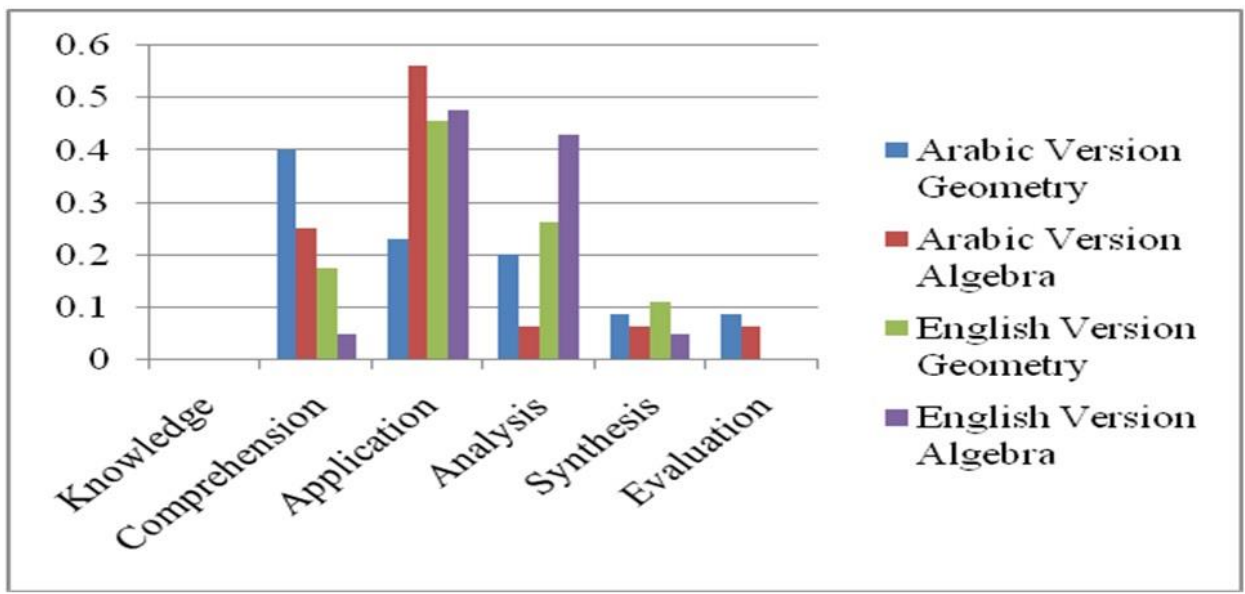

Figure 1. The distribution of each level of Bloom's Taxonomy for both versions

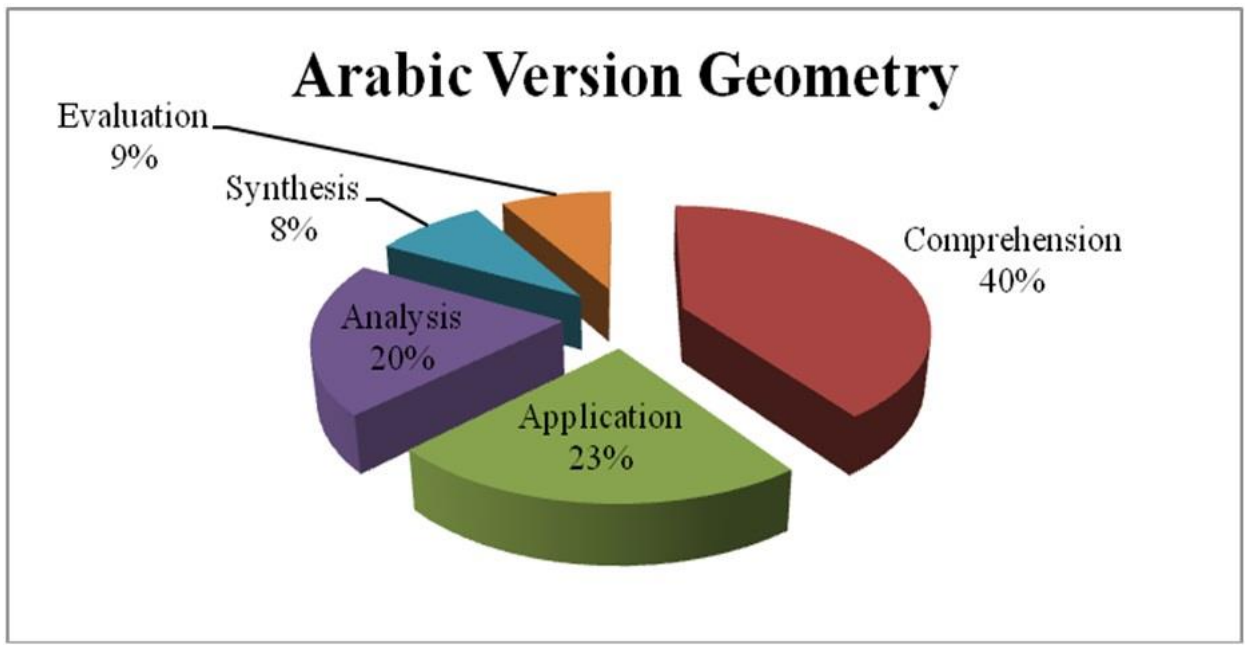

Figure 2. The distribution of each level of Bloom's Taxonomy for Arabic version for geometry

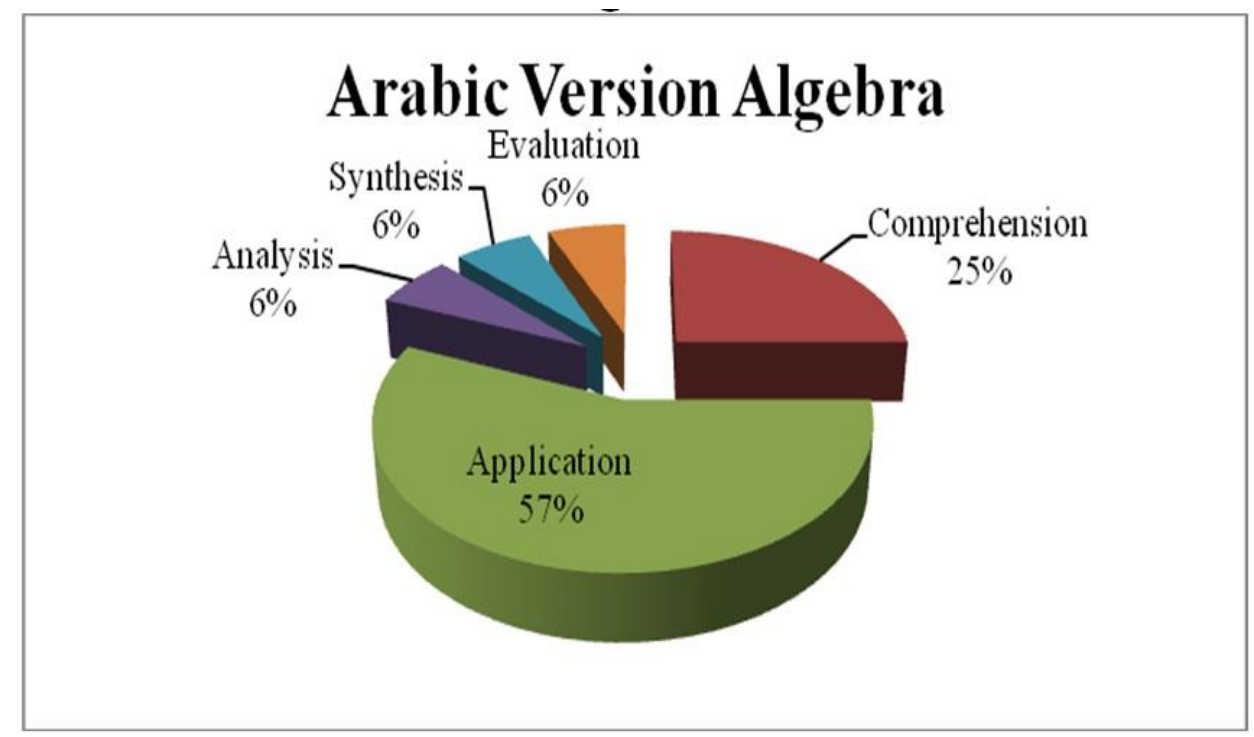

Figure 3. The distribution of each level of Bloom's Taxonomy for Arabic version for algebra 


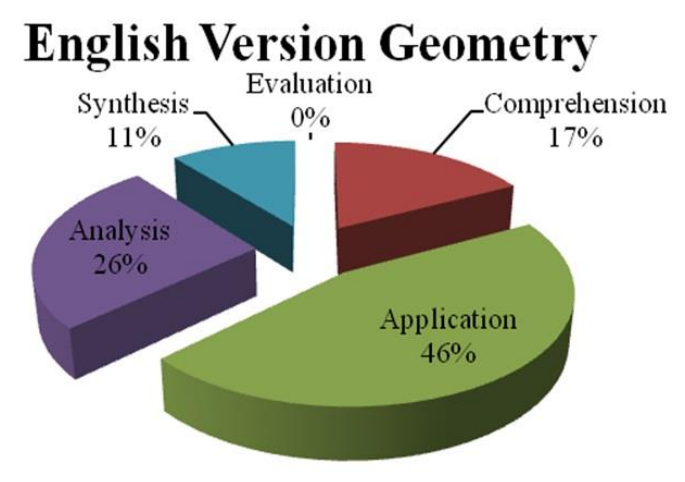

Figure 4. The distribution of each level of Bloom's Taxonomy for English version for geometry

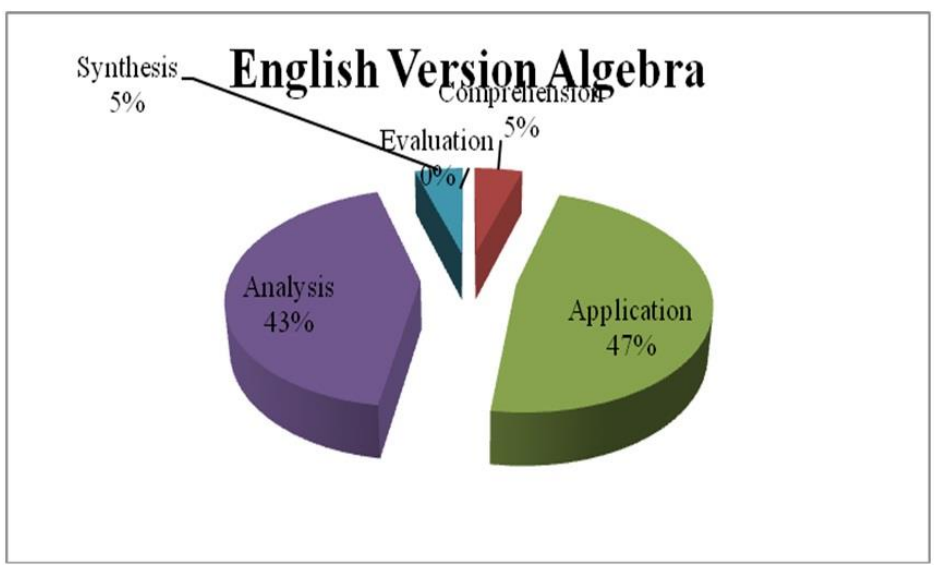

Figure 5. The distribution of each level of Bloom's Taxonomy for English version for Algebra

Table 7. The percentages of each level of Bloom's Taxonomy

\begin{tabular}{|c|c|c|c|c|c|c|c|c|}
\hline Version & Chapters & Knowledge & Comprehension & Application & Analysis & Synthesis & Evaluation & Total \\
\hline \multirow[t]{2}{*}{ Arabic } & Geometry & & $40.00 \%$ & $22.86 \%$ & $20.00 \%$ & $8.57 \%$ & $8.57 \%$ & $100.00 \%$ \\
\hline & Algebra & & $25.00 \%$ & $56.25 \%$ & $6.25 \%$ & $6.25 \%$ & $6.25 \%$ & $100.00 \%$ \\
\hline \multirow[t]{2}{*}{ English } & Geometry & & $17.39 \%$ & $45.65 \%$ & $26.09 \%$ & $10.87 \%$ & & $100.00 \%$ \\
\hline & Algebra & & $4.76 \%$ & $47.62 \%$ & $42.86 \%$ & $4.76 \%$ & & $100.00 \%$ \\
\hline
\end{tabular}

According to Table 7 , it can be concluded that the percentages of educational objectives in the two textbook versions are different. For the Arabic version and for the Geometry chapters, the educational objectives percentages ranged from 40.00\% (Comprehension) to 8.57\% (Synthesis and Evaluation), and the educational objectives percentages for the Algebra chapters ranged from 56.25\% (Application) to 6.25\% (Synthesis and Evaluation). However, in the English version, the educational objectives percentages for Geometry chapters ranged from $45.65 \%$ (Application) to $10.87 \%$ (Synthesis), and the educational objective percentages for the Algebra chapters ranged from $47.62 \%$ (Application) to $4.76 \%$ (Comprehension and Synthesis).

In order to compare between the two versions, the lower three levels' percentages of Bloom's taxonomy were combined. In the Arabic version for the geometry chapters, $62.86 \%$ of the educational objectives were in the lower levels of Bloom's taxonomy, whereas, in the English version, $63.04 \%$ of them were in the lower levels of Bloom's Taxonomy. As well as, we can notice that in the Arabic version 79.11\% of the educational objectives were in the Application level. However, in the English version, 93.27\% of the educational objectives were in the application level, which indicates that the English version gives more concentration to master mathematical skills than the Arabic one. Along with that, the English version gives more attention to the higher order thinking skills with a percentage of $68.95 \%$ compare to $26.25 \%$ for the Arabic one. 


\section{CONCLUSION}

From the data analysis presented in this paper, it has been noticed that there are big differences between the two versions regarding the percentages of the educational objectives. The English version showed more attention to the lower and higher order skills than the Arabic version. However, The Arabic version allocated more time to the geometry chapters with a percentage of $55.29 \%$ than the English version with a percentage of $41.40 \%$, whereas the English version of the textbook gives more time to the Algebra chapters with a percentage of $27.14 \%$ than the Arabic one with a percentage of $17.14 \%$.

The English version of the mathematics textbook gives more concentration to the higher-order thinking skills than the Arabic version. Moreover, more applications were presented on the English version than the Arabic one. It also shows more applications of the mathematical problems in real life situations than the Arabic one.

The educational objectives distribution showed that both versions did not give attention to knowledge level, which is considered in my opinion a very serious disadvantage in designing any curriculum. The curriculum has first to build the students' knowledge to make sure that they will use that knowledge in other situations effectively.

Since curriculum analysis can raise many issues relating to accountability and effectiveness, I do believe that more analysis of mathematics textbooks for other grades is required in order to develop students' learning process. Furthermore, curriculum analysis should be part of the usual schools activities, because that requires additional time, which cannot be provided in the schooling time (Sowell 2005, p.38). In addition to that, an analysis of tests used by teachers of both textbook versions is required in order to find out the degree to which these tests fulfill the learning theories and educational objectives. As well as, the curricula designers have to connect the mathematics textbooks chapters with each other; because I have noticed that in both versions, there is a kind of distinction between the textbooks' contents.

\section{REFERENCES}

Abosalem, Y., 2009. evaluating grade ten-mathematics textbook in abu dhabi from teachers' perspective. Unpublished manuscripts.

Anderson, L.W., Krathwohl, D.R. and Bloom, B.S., 2001. A taxonomy for learning, teaching, and assessing: A revision of Bloom's taxonomy of educational objectives. Allyn \& Bacon.

Ayvaci, H.S. and Turkdogan, A., 2010. Analyzing "science and technology course exam questions"according to revised Bloom Taxonomy. Journal of Turkish Science Education, 7(1), pp. 13-25.

Bloom B.S., 1956. Taxonomy of educational objectives, Handbook I: The Cognitive domain. New York: David McKay Co Inc. In Learning and Teaching: Bloom's Taxonomy. [Online]. Available from http://www.learningandteaching.info/learning/bloomtax.htm [Accessed 15 July 2010].

Bulut, M., 2007. Curriculum reform in Turkey: A case of primary school mathematics curriculum. Eurasia Journal of Mathematics, Science \& Technology Education, 3(3), pp 203-212.

Chávez, O., 2003. From the textbook to the enacted curriculum: Textbook use in the middle school mathematics classroom (Doctoral dissertation, University of Missouri-Columbia).

Ball, D.L. and Cohen, D.K., 1996. Reform by the book: What is: Or might be: The role of curriculum materials in teacher learning and instructional reform? Educational researcher, 25(9), pp.6-14.

Deborah, S., 1998. Learning mathematics for teaching: from teachers' seminar to the classroom. Journal of Mathematics Teacher Education, 1, pp. 55-87.

Haggarty, L. and Pepin, B., 2002. An investigation of mathematics textbooks and their use in English, French and German classrooms: Who gets an opportunity to learn what? British Educational Research Journal, 28(4), 567-590.

Evelyn J. S., 2005. Curriculum an Investigative Introduction. (3 ${ }^{\text {rd }}$ ed.). New Jersey: Pearson, Merrill Prentice Hall, Upper Saddle River.

Gerald, K. and Li, Y., 2009. Curriculum research to improve teaching and learning: national and cross- national studies. ZDM- The International Journal on Mathematics Education, 41, pp. 709-715.

Heirdsfield, A.M., Warren, E. and Dole, S., 2008. The use of a new mathematics text book scheme-support or impediment. Paper presented at the Annual Conference of the Australian Association of Research in Education, Perth, Australia (25-29 November, 2007). [Online]. Available from http://www.aare.edu.au/07pap/hei07174.pdf [Accessed 18 July 2010].

Hirsch C.R. and Reys, B.J., 2009. Mathematics curriculum: a vehicle for school improvement. ZDM-The International Journal on Mathematics Education, 41, pp. 749-761.

Kline, M., 1973. Why Johnny can't add: the failure of the new math. New York: St. Martin's Press.

Lebanon, L., 2008. Mathematics, grade-10, United Arab Emirates student book. (2nd ed.). Arab Educators, Beirut, Lebanon.

Li, Y., Chen, X. and Kulm, G., 2009. Mathematics teachers' practices and thinking in lesson plan development: A case of teaching fraction division.ZDM, 41(6), pp.717-731. 
Li, Y., Zhang, J. and Ma, T., 2009. Approaches and practices in developing school mathematics textbooks in China. ZDM-The International Journal on Mathematics Education, 41(6), pp.733-748.

Li, Y., 2002. Knowing, understanding and exploring the content and formation of curriculum materials: A Chinese approach to empower prospective elementary school teachers pedagogically. International Journal of Educational Research, 37(2), pp.179-193.

Madaus, G.F. and Kellaghan, T., 1992. Curriculum evaluation and assessment (pp.119-154.) In Handbook of research on curriculum. New York: Macmillan; Toronto: Collier Macmillan Canada; Maxwell Macmillan International Philip

McServeny, et. al., 2008. New signpost mathematics for the United Arab Emirates student book for grade 10. Person Australia Group Pty Ltd.

National Research Council, 2004. On evaluating curricular effectiveness: Judging the quality of K-12 mathematics evaluations. Washington, DC: Mathematical Science Education Board, Center for Education.

Nie, B., Cai, J. and Moyer, J., 2009. How a standards-based mathematics curriculum differs from a traditional curriculum with a focus on intended treatments of the ideas of variable. ZDM- The International Journal on Mathematics Education, 41, pp.777-792.

Nicol, C. and Crespo, S., 2006. Learning to teach with mathematics textbooks: How pre-service teachers interpret and use curriculum materials. Educational Studies in Mathematics, 62, pp. 331-355.

Obara, S. and Sloan, M., 2009. Classroom experiences with new curriculum materials during the implementation of performance standards in mathematics: A case study of teachers coping with change. International Journal of Science and Mathematics Education, 7(4), pp. 1-24.

Özgeldi, M., 2010. Changing curriculum, textbook, and teaching: The case of teachers' use of mathematics textbooks in Turkey. Paper presented at European Educational Research Association (Ecer). [Online].Available from http://www.eeraecer.eu/ecer-programmes/conference/ecer-2010/contribution/1133-2/?no_cache=1\&cHash=e5584c1aae.

[Accessed 18 July 2010].

Pepin, B. and Haggarty, L.M., 2001. Mathematics textbooks and their use in English, French and German classrooms: A way to understand teaching and learning cultures. ZDM- The International Journal on Mathematics Education, 33(5), pp 158-175.

Remillard, J.T., 2005. Examining key concepts in research on teachers' use of mathematics curricula. Review of Educational Research, 75(2), pp. 211-246.

Reys, R. E., Reys, B. J. and Lapan, R., et al., 2003. Assessing the impact of standard - based middle grades mathematics curriculum materials on student achievement. Journal of Research in Mathematics Education, 34, pp. 74-95.

Riordan, J.E. and Noyce, P.E., 2001. The impact of two standards based mathematics curricula on student achievement in Massachusetts. Journal for Research in Mathematics Education, 32, pp. 368-99.

Robitaille, D.F. and Travers, K.J., 1992. International studies of achievement in mathematics. In D. A. Grouws (Ed.), Handbook of research on mathematics teaching and learning (pp. 687-709). New York: Macmillan; Reston, VA: National Council of Teachers of Mathematics.

Ross, J.A., Xu, Y.M. and Ford, J., 2008. The effects of a teacher in-service on low -achieving grade 7 and 8 mathematics students. School Science and Mathematics, 108(8), pp. 362-379.

Ronald C.D., 1996. Curriculum improvement decision making and processes. MA, USA: Allyn \& Bacon, Needham Heights.

Rontzur, M.A., Simon, K.H. and Margaret, K., 2001. An account of teacher's perspective on learning and teaching mathematics: Implications for teachers' development. Journal of Mathematics Teacher Education, 4, pp. 227-254.

Scott, H.V., 1972. The taxonomy of educational objectives as a curriculum analysis tool: A solution to some problems encountered while coding activities. Science Education, 56(3), pp. 411-415.

Sowell, E.J., 2005. Curriculum: An integrative introduction. Upper Saddle River, NJ: Pearson.

Tornroos, J., 2005. Mathematics textbook, opportunity to learn and student achievement. Studies in Educational Evaluation, 31, pp. 315-327.

Verschaffel, L., 2002. Taking the Modeling Perspective Seriously at the Elementary School Level: Promises and Pitfalls. Paper presented at the annual meeting of the North American Chapter of the International Group for the Psychology of Mathematics Education, Delta Chelsea Hotel, Toronto, Ontario, Canada [online]. Available from: http://www.allacademic.com/meta/p117675_index.html. [Accessed 02 December 2009].

Weiss, I.R., Banilower, E.R., McMahon, K.C. and Smith, P.S., 2001. Report of the 2000 national survey of science and mathematics education.

Ziegler, D. and Chapman, O., 2004. Teaching an application-oriented high school mathematics curriculum: The teacher's perspective. North American Chapter of the International Group for the Psychology of Mathematics Education October 2004 Toronto, Ontario, Canada, p.1380. 